\title{
Consumer protection in the conditions of the Slovak Republic in line with the harmonization of legislation and consumer rights within the EU
}

\author{
Stanislava Deáková ${ }^{*}$ and Sylvia Bukovová ${ }^{1}$ \\ ${ }^{1}$ University of Economics, Faculty of Business Management, Dolnozemská cesta 1, 85235 \\ Bratislava, Slovakia
}

\begin{abstract}
The paper is devoted to analyzing the conditions and possibilities of assisting consumers in protecting their consumer rights. As Slovakia is a member of the EU, it is necessary to include the conditions resulting from harmonizing the law within the Union. This paper points out different possibilities of consumer protection documented in the research part by evaluating data available in statistical sources. We also point out the current state of the frequency of initiated individual proceedings, the analysis of which is used to formulate the conclusions and recommendations of the scientific study.
\end{abstract}

\section{Introduction}

Consumer protection is now an increasingly topical issue connected with the development trends of the global business environment in the form of globalization, intensification, intellectualization, humanization, greening, flexibility, and acceleration. The global business environment is part of the business environment and, therefore, significantly shapes the relations between businesses and the entities in their vicinity through its global reach. Another essential part is the general surroundings of the business entity, which relates to the entities and relationships built between them in the economy of the given state through elements such as the state, lower territorial unit, suppliers, customers, competitors, and the public. When building relationships, it is necessary to point out the ties according to their nature, i.e., authoritative or partners, through which they communicate. At the level of the specific surroundings, we perceive communication between entities in a specific space and time [1,2]. We analyze processes and tools, institutional and legislative provision of consumer protection in the Slovak Republic. We point out the possibilities provided by the legislation and individual organizations dealing with support and assistance to consumers within the framework of the rules of the Slovak Republic.

\subsection{The current situation in the field of consumer protection in the Slovak Republic}

\footnotetext{
${ }^{*}$ Corresponding autor: stanislava.deakova@euba.sk
} 
As we mentioned in the introduction, current global trends contribute to the rapid development of new technologies and materials, providing the possibility of a free transfer of goods and providing services without being limited by the borders of a given country. Scientific and technological progress accelerates communication processes, which is also reflected in expanding internet services while providing goods and services and the subsequent payments for the goods provided. These facts are only a fraction of the impact of global trends. [3]

\subsubsection{Advantages and disadvantages of the impact of business environment trends}

On the one hand, the business environment creates wider opportunities to meet the demand for goods and services without unnecessary barriers for consumers and entrepreneurs. Consumers can choose from a much broader range of products, while at the same time, the internet space and some applications allow consumers to easily find and compare different criteria for the choice of goods. The fast availability of offered goods and services from virtually any place in the world is also tempting. The development of a sophisticated logistics system also contributes significantly to this. [4-5]

Negative impacts also accompany the opening of new opportunities and horizons for entrepreneurs and consumers. Among the most common are the possibilities of cyber attacks and the misuse of databases with personal data, access codes and passwords to collect money from paying consumers' accounts. The second group of risks is due to the possibility of choosing a wide range of products, where the customer is unable (despite access to information) to navigate through the quality of the goods and services provided, mainly due to the provision of false information on the Internet, which is very difficult to verify. Counterfeit goods of renowned brands, products made from harmful materials, or products made in countries where the labor is exploited, working under inhumane, often harmful conditions and just for a minimum wage that is not sufficient to cover even necessities are available on the market. In such countries, we are also faced with an undesirable impact of production on the environment because of missing legislation or control of compliance with environmental protection. [5-12]

The above shows that countries seek to harmonize legislation and trade rules within the cooperating countries. For us, as a country that is part of the EU, this area has the most significant impact. In the following section, we present a cross-section of the basic legal standards and institutions that help consumers ensure that consumer rights are protected.

\subsubsection{Legislative and institutional protection of consumer rights in the Slovak Republic}

The state is an essential institution ensuring the legal framework and compliance with consumer protection rules. Pursuant to $\S 19 \mathrm{sec} .1 \mathrm{sec}$. 2 letter e) of the Act no. 250/2007 Coll. on consumer protection and the amendment of the Act of the Slovak National Council no. 372/1990 Coll. on offences as amended, the Ministry of Economy of the Slovak Republic (MHSR) within its competence in the field of consumer protection informs consumers about their rights and obligations [13]. On its website, the MHSR provides clear information in the following categories: [13]
- consumer information
- $\quad$ European Consumer Center in the Slovak Republic
- consumer associations
- consumer protection legislation in English,
- consumer protection legislation,
- documents concerning consumer protection, 
- $\quad$ safety of consumer products,

- EU consumer protection legislation,

- alternative resolution of consumer disputes,

- administrative action.

The Slovak Trade Inspection (SOI) is the state control body of the internal market regarding consumer protection with nationwide competence. It is subordinate to the MHSR. Act no. 128/2002 Coll. on state control of the internal market in consumer protection matters as amended (hereinafter referred to as the "Act") is a legal regulation determining SOI competencies. This law defines the rights and obligations of SOI in general, but also in relation to special regulations governing consumer protection in specific areas.

The core activities of the SOI are: [14]

- $\quad$ to inspect and supervise the compliance with obligations arising from 350 legal regulations,

- $\quad$ to impose on-the-spot measures, protective measures, interim measures and fines for breach of obligations arising from legal regulations within its supervisory competence,

- $\quad$ to propose, based on facts established by an inspection, the suspension or cancellation of trade licence,

- to provide professional and methodological assistance to district authorities, municipalities, consumer associations and other legal persons established for consumer protection,

- SOI provides advice to consumers,

- cooperates with state and public authorities, consumer associations, supervisory authorities of other Member States with the European Economic Commission for Europe and the relevant UN bodies in the exchange of information in the field of market surveillance,

- collects fines and receivables from business entities and natural persons,

- informs about the danger to the life, health and property of consumers or the environment by selling dangerous products,

- develops and renews a Manual on Fuel Consumption and CO2 Emissions according to the Government Regulation no. 384/2004 coll. on the availability of consumer information on fuel consumption and $\mathrm{CO} 2$ emissions in the sale and leasing of new cars,

- handles consumer claims and complaints;

- $\quad$ clarifies the infringements.

Given the limited scope of the paper, we do not provide more detailed information about the different categories mentioned in this section of the paper. Links to the detailed information are provided in the references.

\section{Research design}

The research aimed to point out, in theory, an overview of the basic approaches to the given issue. In the research section, we focused on statistical processing, assessment and analysis of the results of inspection activities, and evaluating cases that SOI dealt with in the monitored period from 2016 and 2019, emphasizing the development, structure of areas and inspection results. The research outputs are presented in a clear graphical and tabular form. We used mainly scientific articles in indexed journals and scientific monographs as sources of information. We used data from the available statistical sources of quoted institutions and SOI annual reports in the application section. We used general and specific scientific methods to process the research, such as analysis, synthesis, abstraction, induction, deduction, comparison, and standard mathematical and statistical methods. 


\section{Results and Discussion}

The research part focuses on analyzing the outputs of SOI inspections from 2016 to 2019, with subsequent comparison and evaluation of changes in the cases in the monitored period.

\subsection{SOI Inspection Activity}

The SOI's inspection activities focus on those areas where the consumers cannot effectively protect their rights. These include, in particular, health and safety, misleading advertising, covert harm, discrimination, unsolicited advertising, the compliance of non-food products with technical requirements, the activity of travel agencies and accommodation facilities and the provision of services. In particular, emphasis is placed on protecting consumers' economic interests, their protection against unfair commercial practices or unacceptable terms in consumer contracts.

The development in the number of inspections and the results of the SOI inspection activities in the monitored period are shown in Tables 1 to 4 :

Table 1. Inspections in establishments aimed at selling products and providing services to consumers in the internal market.

\begin{tabular}{|c|c|c|c|c|c|c|}
\hline Year & $\mathbf{2 0 1 6}$ & $\mathbf{2 0 1 7}$ & $\mathbf{2 0 1 8}$ & $\mathbf{2 0 1 9}$ & \multicolumn{2}{|c|}{ Change Index 2019/2016 } \\
\hline $\begin{array}{c}\text { Number of } \\
\text { checks }\end{array}$ & 16867 & 16846 & 17636 & 16720 & -147 & $-0,87 \%$ \\
\hline $\begin{array}{c}\text { On the basis } \\
\text { of the } \\
\text { complaints }\end{array}$ & 3366 & 3167 & 3078 & 2384 & -982 & $-29,17 \%$ \\
\hline Shortcomings & 5906 & 5864 & 5791 & 5214 & -692 & $-11,70 \%$ \\
\hline
\end{tabular}

Source: own table [15-19]

Inspections in the establishments selling products and providing services to consumers in the internal market included the areas of claim processes, the right of withdrawal from the contract, the possibility of refunds on sales via the Internet, disagreement with expert judgement, flight delays, etc.

Most inspections were carried out in 2018, the least in 2019. The number of inspections decreased by 147 checks (almost 1\%) in the monitored period compared to the base year. Based on input from consumers, the most inspections were carried out in 2016, the least in 2019. There was a decrease of $982(29.17 \%)$ in the inspections performed based on submissions in the given period. The highest number of shortcomings was identified in 2016, the lowest in 2019. A positive trend is a decrease in the detected shortcomings in the number of 692 inspections $(-11.70 \%)$.

Table 2. Results of inspections in establishments for the sale of products and providing services to consumers in the internal market.

\begin{tabular}{|l|c|c|c|c|c|c|}
\hline Year & $\mathbf{2 0 1 6}$ & $\mathbf{2 0 1 7}$ & $\mathbf{2 0 1 8}$ & $\mathbf{2 0 1 9}$ & \multicolumn{2}{|c|}{$\begin{array}{c}\text { Change Index } \\
\mathbf{2 0 1 9 / 2 0 1 6}\end{array}$} \\
\hline $\begin{array}{c}\text { Suspended sale of } \\
\text { goods types }\end{array}$ & 7386 & 10708 & 8525 & 9922 & +2536 & $+34,34 \%$ \\
\hline Value in Eur & 688496 & $\begin{array}{c}1 \\
486419\end{array}$ & $\begin{array}{c}3 \\
075058\end{array}$ & 1572350 & +883854 & $+128,37 \%$ \\
\hline
\end{tabular}

Source: own table [15-19]

Based on the performed inspections and identified shortcomings, the sale of the various goods has been suspended. The most significant number was recorded in 2017, the lowest in 2016. The value of goods whose sales were suspended showed the lowest value in 2016, the 
highest in 2018. In 2019, compared to 2016, the number of types of suspended goods increased by 2,536 (34.34\%), its value increased by EUR 883,854 (128.37\%).

Table 3. The most represented assortment in inspected establishments, aimed at selling products and providing services to consumers in the internal market in $\%$.

\begin{tabular}{|c|c|c|c|c|c|}
\hline Year & $\mathbf{2 0 1 6}$ & $\mathbf{2 0 1 7}$ & $\mathbf{2 0 1 8}$ & $\mathbf{2 0 1 9}$ & $\begin{array}{c}\text { Change Index } \\
\mathbf{2 0 1 9} / \mathbf{2 0 1 6}\end{array}$ \\
\hline Travel agents & 1,26 & 0,59 & 0,71 & 1,97 & $+0,71$ \\
\hline Energy & 3,76 & 4,55 & 4,00 & 3,56 & -0.20 \\
\hline Non-food goods & 60,50 & 59,89 & 58,95 & 62,89 & $+2,39$ \\
\hline Hospitality facilities & 8,64 & 9,75 & 10,68 & 10,98 & $+2,34$ \\
\hline Food products & 10,03 & 7,46 & 6,99 & 5,91 & $-4,12$ \\
\hline Various goods & 2,89 & 3,63 & 4,13 & 2,78 & $-0,11$ \\
\hline Services & 10,07 & 11,20 & 11,87 & 10,12 & $+0,05$ \\
\hline Accomodation & 2,84 & 2,93 & 2,68 & 1,80 & $-1,04$ \\
\hline
\end{tabular}

Source: own proceedings [15-19]

Table 3 shows that the largest share of inspected operations in the monitored period was in producing non-food goods, the lowest share being travel agents. In fact, the structure of the inspected range does not change significantly in the monitored period; in 2019, compared to the base year, inspections decreased the most in the area of food products (4.12), the least in the area of various goods $(0.11)$. The most significant increase was recorded in non-food goods (2.39), the smallest in services $(0.05 \%)$.

Table 4. Energy inspections.

\begin{tabular}{|c|c|c|c|c|c|c|}
\hline Year & $\mathbf{2 0 1 6}$ & $\mathbf{2 0 1 7}$ & $\mathbf{2 0 1 8}$ & $\mathbf{2 0 1 9}$ & \multicolumn{2}{|c|}{ Change Index 2019/2016 } \\
\hline $\begin{array}{c}\text { Number of } \\
\text { inspections }\end{array}$ & 634 & 767 & 705 & 596 & -38 & $-6,00 \%$ \\
\hline Shortcomings & 172 & 221 & 256 & 215 & +43 & $+25,00 \%$ \\
\hline
\end{tabular}

Source: own table [15-19]

In the area of energy inspection, the SOI considers it necessary to supervise the whole range of competencies, such as the energy efficiency of buildings, the area of biofuels and illegal gas consumption or the check of air-conditioning systems. The inspections were carried out mainly in the heating sector (Thermal Energy Act). The most negative findings were in budgeting the cost of heat and hot water for final consumers. The number of energy inspections was highest in 2017 (767), the lowest in 2019 (596). The resulting decrease was 38 inspections (6.00\%). The highest number of shortcomings was identified in 2018, the lowest in 2016. The number of shortcomings increased by $43(25 \%)$ over the monitored period.

\subsection{Addressing consumer complaints}

The inquiries, suggestions and requests received from consumers included, in particular, the claim process, the right to withdraw from the contract, the possibility of a refund when selling via the Internet, disagreement with the expert judgement, flight delays, etc. Their structure remains almost identical over the monitored period.

The number of complaints and their structure over the monitored period is illustrated in Tables 5 to 8 .

Table 5. Complaints received, requests for advice and notifications.

\begin{tabular}{|c|c|c|c|c|c|c|}
\hline Year & $\mathbf{2 0 1 6}$ & $\mathbf{2 0 1 7}$ & $\mathbf{2 0 1 8}$ & $\mathbf{2 0 1 9}$ & \multicolumn{2}{c|}{ Change Index 2019/2016 } \\
\hline Accepted & 10014 & 9957 & 9254 & 9249 & -765 & $-7,64 \%$ \\
\hline Examined & 3366 & 3167 & 3078 & 2384 & -982 & $-29,17 \%$ \\
\hline
\end{tabular}




\begin{tabular}{|c|c|c|c|c|c|c|}
\hline Justified & 1499 & 1412 & 1251 & 1010 & -489 & $-32,62 \%$ \\
\hline $\begin{array}{c}\text { Subject matter of } \\
\text { the complaint } \\
\text { unconfirmed }\end{array}$ & 1867 & 1755 & 1827 & 1374 & -493 & $-26,41 \%$ \\
\hline
\end{tabular}

Source: own table [15-19]

The highest number of complaints was dealt with by the SOI in 2016, the lowest in 2019. The resulting decrease is 765 complaints $(7.64 \%)$. During the monitored period, the number of investigated claims decreased by 982 (29,17\%), justified complaints by 489 (32,62\%) complaints with the unconfirmed subject matter by 493 (26.41\%).

Table 6. Inputs received by region.

\begin{tabular}{|c|c|c|c|c|c|c|}
\hline year & $\mathbf{2 0 1 6}$ & $\mathbf{2 0 1 7}$ & $\mathbf{2 0 1 8}$ & $\mathbf{2 0 1 9}$ & \multicolumn{2}{c|}{ Change Index 2019/2016 } \\
\hline Energy & 445 & 379 & 327 & 260 & -185 & $-41,57 \%$ \\
\hline services & 2451 & 2557 & 2446 & 2460 & +9 & $+0,37 \%$ \\
\hline
\end{tabular}

Source: own table [15 -19]

The number of complaints in services significantly exceeds the number of energy complaints every year in the monitored period. However, in energy, the number of complaints decreased significantly in 2019 compared to 2016 - by 185 (41.57\%), while in services, it increased very slightly - by $9(0.37 \%)$.

Table 7. Most represented areas of service by type in the complaints received.

\begin{tabular}{|c|c|c|c|c|c|c|}
\hline Year & $\mathbf{2 0 1 6}$ & $\mathbf{2 0 1 7}$ & $\mathbf{2 0 1 8}$ & $\mathbf{2 0 1 9}$ & \multicolumn{2}{c|}{$\begin{array}{c}\text { Change Index } \\
\mathbf{2 0 1 9} / \mathbf{2 0 1 6}\end{array}$} \\
\hline $\begin{array}{c}\text { Services related to } \\
\text { the use of the } \\
\text { apartment }\end{array}$ & 438 & 512 & 507 & 384 & -54 & $-12,33 \%$ \\
\hline Internet services & 166 & 104 & $\mathrm{x}$ & $\mathrm{x}$ & $\mathrm{x}$ & $\mathrm{x}$ \\
\hline Hospitality services & $\mathrm{x}$ & 319 & 498 & 406 & $\mathrm{x}$ & $\mathrm{x}$ \\
\hline $\begin{array}{c}\text { Travel agents and } \\
\text { agencies }\end{array}$ & 157 & 138 & 154 & 226 & +69 & $+43,95 \%$ \\
\hline Construction services & 106 & 199 & 133 & 174 & +68 & $+64,15 \%$ \\
\hline Air transport & 111 & 165 & 151 & 290 & +179 & $+161,26 \%$ \\
\hline Advertising & 97 & $\mathrm{x}$ & $\mathrm{x}$ & $\mathrm{x}$ & $\mathrm{x}$ & $\mathrm{x}$ \\
\hline
\end{tabular}

Source: own table [15-19]

During the monitored period, consumer complaints received by SOI were mainly related to the use of apartments. However, in the results, they decreased by 54 (12.33\%). Hospitality services recorded significant growth in 2018. The complaints were also related to travel agency and agency services, construction services and air transport. The highest growth in 2019 compared to 2016 was in the number of complaints in air transport - an increase by 179 $(161.26 \%)$, the lowest in construction services - an increase by $68(64.15 \%)$, the decrease was recorded in the area of internet services and the advertising.

Table 8. The most represented areas of sale of non-food goods in the complaints received.

\begin{tabular}{|c|c|c|c|c|c|c|}
\hline Year & $\mathbf{2 0 1 6}$ & $\mathbf{2 0 1 7}$ & $\mathbf{2 0 1 8}$ & $\mathbf{2 0 1 9}$ & \multicolumn{2}{|c|}{$\begin{array}{c}\text { Change Index } \\
\mathbf{2 0 1 9 / 2 0 1 6}\end{array}$} \\
\hline Footwear & 654 & 583 & 487 & 425 & -229 & $-35,02 \%$ \\
\hline Household articles & 460 & 165 & 84 & 124 & -336 & $-73,04 \%$ \\
\hline Textile products & 422 & 510 & 425 & 523 & +101 & $+23,93 \%$ \\
\hline Mobile phones & 364 & 394 & 328 & 253 & -111 & $-30,49 \%$ \\
\hline Furniture & $\mathrm{x}$ & 245 & 312 & 322 & $\mathrm{x}$ & $\mathrm{x}$ \\
\hline Household appliances & 238 & 262 & 207 & 237 & -1 & $-0,42 \%$ \\
\hline
\end{tabular}




\begin{tabular}{|c|c|c|c|c|c|c|}
\hline Building material & 196 & 162 & 168 & 133 & -63 & $-32,14 \%$ \\
\hline Sports equipment & 70 & 70 & $\mathrm{x}$ & $\mathrm{x}$ & $\mathrm{x}$ & $\mathrm{x}$ \\
\hline Motor vehicles & 183 & 157 & 169 & 153 & -30 & $-16,39$ \\
\hline Computing & 173 & 185 & 130 & 117 & -56 & $-32,37 \%$ \\
\hline
\end{tabular}

Source: own table [15-19]

In non-food goods sales, the most significant increase in consumer complaints concerns the quality of purchased footwear, the claim procedure and the consequent disagreement with the conclusions of expert judgements, based on which the seller rejects consumer complaints. The most represented were the complaints or inquiries connected with claim procedure, internet sales, withdrawal rights. Numerous representation in the complaints belongs to filing the claims in footwear, textile products, mobile phones, household appliances, motor vehicles, and computing sectors. In the monitored period, the number of household articles complaints decreased the most - by $336(73.04 \%)$, the least - by $1(0.42 \%)$ the number of complaints in household appliances, no complaint was made in sports equipment and furniture. The increase in complaints was recorded only in textile products by $101(23.93 \%)$.

\subsection{SOI Punitive Activity}

SOI is entitled to impose, on an inspected person with found shortcomings, based on the inspection results carried out at the point of sale or services provision, not only an obligation to take measures for their removal but also a fine. The amount of fine depends on several factors, such as the duration of the unlawful conduct, the seriousness of the shortcoming, or the consequences caused by such unlawful conduct. If repeated and serious shortcomings are identified in performing the business activities, the SOI may also submit a proposal to revoke or suspend the trade license.

The development and results of the SOI's punitive activities over the monitored period are documented in Tables 9 to 12 :

Table 9. Fines and their value.

\begin{tabular}{|c|c|c|c|c|c|c|}
\hline year & $\mathbf{2 0 1 6}$ & $\mathbf{2 0 1 7}$ & $\mathbf{2 0 1 8}$ & $\mathbf{2 0 1 9}$ & \multicolumn{2}{|c|}{ Change Index 2019/2016 } \\
\hline $\begin{array}{c}\text { Number of } \\
\text { fines }\end{array}$ & 3442 & 3745 & 4269 & 3570 & +128 & $+3,72 \%$ \\
\hline $\begin{array}{c}\text { Value of } \\
\text { fines in Eur }\end{array}$ & 2498996 & 2488738 & 3210090 & 2665982 & +166986 & $+6,68 \%$ \\
\hline
\end{tabular}

Source: own table [15 -19]

In the monitored period, the highest number of fines with the highest value was in 2018 , the lowest number of fines with the lowest value was recorded in 2016. The resulting change was an increase in the number of fines by $128(3.72 \%)$ and an increase in the value of fines by $166,986(6.68 \%)$.

Table 10. Pecuniary fines imposed on FO (natural persons) and PO (legal persons).

\begin{tabular}{|l|c|c|c|c|c|c|}
\hline \multicolumn{1}{|c|}{ year } & $\mathbf{2 0 1 6}$ & $\mathbf{2 0 1 7}$ & $\mathbf{2 0 1 8}$ & $\mathbf{2 0 1 9}$ & \multicolumn{2}{c|}{$\begin{array}{c}\text { Change Index } \\
\mathbf{2 0 1 9 / 2 0 1 6}\end{array}$} \\
\hline Number of FO & 981 & 1246 & 1462 & 1102 & +121 & $+12,33 \%$ \\
\hline Number of PO & 2314 & 2363 & 2559 & 2275 & -39 & $-1,69 \%$ \\
\hline $\begin{array}{l}\text { Value of fines } \\
\text { in Eur for FO }\end{array}$ & 428218 & 588754 & 745214 & 547075 & +118857 & $+27,76 \%$ \\
\hline $\begin{array}{l}\text { Value of fines } \\
\text { in Eur for PO }\end{array}$ & 1836183 & 1681752 & 2061156 & 1804688 & -31495 & $-1,72 \%$ \\
\hline
\end{tabular}

Source: own table [15-19] 
In the monitored period, the number of fines imposed on FO (natural persons) was significantly lower than that imposed on the PO (legal persons), the lowest in 2016 and the highest in 2018. However, the resulting difference increased by 121 fines $(12.33 \%)$. The number of imposed fines on PO (legal persons) was the lowest in 2019, the highest in 2018, but fell by $39(1.69 \%)$ in the end. A similar trend was also reflected in the value of fines - the value of fines imposed on FO(natural persons) in 2019 increased by EUR 118,857 (27.76\%), the value of fines imposed on PO (legal persons) decreased by EUR 31,495 (1.72\%).

Table 11. Fines for obstruction of inspection.

\begin{tabular}{|c|c|c|c|c|c|c|}
\hline Year & $\mathbf{2 0 1 6}$ & $\mathbf{2 0 1 7}$ & $\mathbf{2 0 1 8}$ & $\mathbf{2 0 1 9}$ & \multicolumn{2}{c|}{ Change Index 2019/2016 } \\
\hline Number & 147 & 136 & 248 & 193 & +46 & $+31,29 \%$ \\
\hline Amount & 234595 & 218232 & 403720 & 314219 & +79624 & $+3,39 \%$ \\
\hline
\end{tabular}

Source: own proceedings [15-19]

The highest number of fines for obstruction of inspection (even with the highest value) was in 2018, the least - with the lowest value - in 2016. The number of fines increased by 46 (31.29\%), their value by $79,624(3.39 \%)$.

Table 12. Proposals for the cancellation or suspension of a trade license due to the detection of repeated and serious shortcomings in the performance of business activities.

\begin{tabular}{|c|c|c|c|c|c|c|}
\hline Year & $\mathbf{2 0 1 6}$ & $\mathbf{2 0 1 7}$ & $\mathbf{2 0 1 8}$ & $\mathbf{2 0 1 9}$ & \multicolumn{2}{c|}{ Change Index 2019/2016 } \\
\hline Number & 8 & 17 & 6 & 14 & +6 & $+75 \%$ \\
\hline
\end{tabular}

Source: own table [15-19]

Most proposals for the cancellation of the trade licence were recorded in 2017, the least in 2018. The resulting difference represents an increase of 6 proposals, representing $75 \%$.

\section{Conclusion}

By analyzing data from the annual reports of the Slovak Trade Inspection on the results of its inspections and punitive activities in Slovakia for the period 2016 to 2018, we found that the number of inspections carried out in the monitored period decreases, fewer inspections are carried out also based on fewer suggestions from consumers, and as a result, the number of detected shortcoming decreases. However, the suspended sale of goods and their value is increasing. A positive trend is a decrease in the complaints received; on the contrary, the decrease in the complaints investigated is negative. The structure of the areas to which consumer complaints relate does not fundamentally change. In the case of punitive activities, the negative development is deepening, the number of fines and their value is increasing, as well as the number of motions to cancel or suspend the trade license to conduct business activities.

\section{Notes}

The article is a partial result of research within the KEGA project no. 002EU-4/2019" Integrating and Systematizing the Results of Scientific Research Activities in the Field of Consumer Protection, with a Primary Focus on Food Security, In Order to Model Adequate Consumer Behaviour ".

\section{References}

1. A. Neumann et al., Business Diagnostics. (Bratislava : Iura Edition, 2012) 
2. S. Deáková, Diagnostic methods and procedures of the company,(Bratislava: Economist, 2013)

3. M.A. Marinov, S.T. Marinova, J.A. Larimo, T. Lepovsky, Characteristics and Future Trends. Internetional Business and Emerging Economy Firms 1, 1 (2020)

4. P. Hamilton, K. A. Getulio, T. Takeshy, Innovation and technology processes in micro and small business. Cogent Business \& Management, 6 (2019)

5. G. K. Amoako. A conceptual framework: Corporate environmental management activities and sustainable competitive. Management Of Environmental Quality, 31(2), 331-347. (2020)

6. T. Cernev, R. Fenner. The importance of achieving foundational Sustainable Development Goals in reducing global risk. Research \& Management Science. 115, 102492, (2020)

7. J. Gunawan, P. Permatasari, C. Tilt. Sustainable development goal disclosures: Do they support responsible consumption and production? Journal Of Cleaner Production, 246, 118989. (2020)

8. J. D'Arcy, P. B. Lowry, Cognitive-affective drivers of employees' daily compliance with information security policies: A multilevel, longitudinal study. Information Systems Journal, 29, 1, 43-69 (2019)

9. V. Bolek, A. Látečková, A. Romanová, F. KORČEK, Factors affecting information security focused on SME and agricultural enterprises. Agris on-line Papers in Economics and Informatics, 8, 4, 37-50 (2016)

10. P. Balozian, D. Leidner, M. Warkentin, Managers' and employees' differing responses to security approaches. Journal of Computer Information Systems, 59, 3, 197-210 (2019)

11. P. Ifinedo, Roles of organizational climate, social bonds, and perceptions of security threats on IS security policy compliance intentions. Information Resources Management Journal, 31, 1, 53-82 (2018)

12. E. Hofmann, M. Rüsch, Industry 4.0 and the Current Status as Well as Future Prospects on Logistics. Computers in Industry, 89 (2017)

13. MHSR. Informácie pre spotrebitel'ov, https://www.mhsr.sk/obchod/ochranaspotrebitela/informacie-pre-spotrebitelov, accessed 2021/10/05

14. SOI. Postavenie, https://www.soi.sk/sk/SOI/Postavenie-SOI.soi, accessed 2021/25/05

15. SOI. 2016 Annual Report, https://www.soi.sk/files/documents/vyrocnespravy/vs\%202016.pdf, accessed 2021/10/05

16. SOI. 2017 Annual Report, https://www.soi.sk/files/documents/kcinnost/vs\%202017.pdf, accessed 2021/25/05

17. SOI. 2018 Annual Report, https://www.soi.sk/files/documents/vyrocnespravy/vs\%202018.pdf, accessed 2021/10/05

18. SOI. 2019 Annual Report, https://www.soi.sk/files/documents/vyrocnespravy/2019/vs\%202019.pdf, accessed 2021/10/05 